Revista "Política y Estrategia" № 136, 2020, pp. 139-144

ISSN 0716-7415 (versión impresa) - ISSN 0719-8027 (versión en línea)

Academia Nacional de Estudios Políticos y Estratégicos

Climate policy and climate change in thinking about National Security and Strategy

in Latin America

Joseph S. Tulchin

\title{
CLIMATE POLICY AND CLIMATE CHANGE IN THINKING ABOUT NA- TIONAL SECURITY AND STRATEGY IN LATIN AMERICA $\infty$
}

\section{JOSEPH S. TULCHIN*}

In october of 2018, the International Panel on Climate Change (IPCC) released a long-awaited report, commissioned under the terms of the 2015 Paris Agreement, in which 174 countries committed to limiting carbon emissions and curtailing the warming of the planet. The findings of the report were sobering: Drawing on thousands of studies, the 91 contributing scientists predicted that, even if every signatory adhered fully to its Paris Agreement commitments, global temperatures would rise by over two degrees celsius by the end of this century. The report also outlined the consequences of such warming, which were far more catastrophic than previously understood. Though it is still theoretically possible to avert the 2 degree threshold, it would require political action on a global scale that is increasingly unlikely. As a result, it is worth asking what are the geopolitical and security implications of such climate changes. More specifically, what does the economic future of Latin America look like in a changed climate, and what political levers remain available to Latin American policymakers seeking to arrest global warming and to protect their people from the consequences of climate change.

How can the nations of the region adapt their thinking on strategic issues and on national security to take into consideration the immediate concerns posed by climate catastrophes, such as tsunamis or forest fires, while also framing policies and strategies that will enhance national and regional well-being in the face of such long term threats as global warming, eliminating or dramatically reducing the use of fossil fuels and preparing for the inundation of coastal areas that include several massive urban areas?

While climate change has been - and continues to be - a politicized subject in the United States and in parts of Europe, Latin American nations for the most part have accepted the changing climate as fact and as worthy of concern. As recently as 2018, polling by political scientists demonstrated that, while only $40 \%$ of North Americans considered unchecked climate change to be a "serious problem," over $75 \%$ of their neighbors to the south, in Central and South America, viewed it as a grave concern. Latin American leaders have, as a result, played prominent roles in global climate negotiations - Christiana Figueres, of Costa Rica, was one of the main authors of the Paris Agreement- and many Latin American nations, including Mexico under the administration of president Enrique Peña Nieto, made unilateral commitments toward limiting carbon emissions that served as a

œ Fecha de recepción: 310320 - Fecha de aceptación: 151220.

- P.Hd en Historia por la Universidad de Harvard. Ha publicado más de 100 artículos académicos y más de 70 libros. Últimas publicaciones: Las relaciones entre Estados Unidos y América Latina: Desafiando la hegemonía norteamericana (Santiago: Fondo de Cultura Económica, 2018); "Regional Security in Latin America after United States Hegemony", capítulo 1 en Marcial A. García Suárez, Rafael Duarte Villa y Brigitte Weiffen, eds., Power Dynamics and Regional Security in Latin America (NY: Palgrave, 2017); "Perú: El impacto de la cultura en la identidad y seguridad peruanas", con Brian Fonseca, en Brian Fonseca y Eduardo A. Gamarra eds., Cultura y seguridad nacional en las Américas (NY: Lexington Books, 2017); América Latina x Estados Unidos. Uma Relação Turbulenta. (São Paulo: editor contexto, 2016); América Latina en la política internacional: desafiando la hegemonía estadounidense (Boulder: LRP, 2016. Estados Unidos. joe.tulchin@gmail.com ORCID: https://orcid.org/0000-0002-8075-5299 
model for the Paris Agreement. The high-level roles played by Latin American nations on questions of climate reflect their tremendous strategic import and present an opportunity for these nations. Their leaders have benefited from the political will to play a vocal role in international meetings on the climate, which has in turn granted them the capacity to exercise national agency in the global community on matters of how to deal with climate change on a regional or global level.

There are indications, though, that climate change is becoming politicized in Latin America as well. In Brazil, for example, the ultra-right-wing president, Jair Bolsonaro, campaigned on the intention of not only withdrawing from the landmark Paris Agreement, but also rescinding Brazil's offer to host the next round of UN climate talks, known as COP25. Though he only followed through on the latter promise, Bolsonaro's campaign for the presidency relied on tropes familiar to US-based political observers, ridiculing climate scientists and environmentalists as determined to sabotage the economy. Bolsonaro has proudly vowed to "open" Brazil's rainforests to logging, mining, and large-scale agriculture, despite the fact that illegal mining and logging are already occurring at unprecedented rates. Vast swathes of the Amazon were set ablaze in 2019 by farmers and ranchers looking to open up land, with the tacit support of the Bolsonaro administration. Scientists estimate that the carbon output from those fires alone makes it nearly impossible that Brazil will succeed in hitting the targets for carbon reduction that it agreed to under the Paris Agreement.

Other conservative Latin American leaders, however, have remained vocally committed to the Paris Agreement, including former president Mauricio Macri of Argentina and current president Sebastian Piñera of Chile. This suggests that climate change is not being politicized in the same way across the region. Macri, the outgoing president of the G-20, oversaw a resolution at the 2018 G-20 summit that reiterated the commitment of the body (with the prominent exception of the United States) to support and adhere to the Paris Agreement. And Piñera, who re-took power from Michelle Bachelet, has signaled a clear intention to continue her climate policies, and is pursuing legislation that would set stricter regional limits on emissions. Piñera also spearheaded a campaign to have Chile host COP25 once it became clear that Bolsonaro's Brazil would not serve as host; ultimately, however, Chile's hosting of the conference was derailed by broad social protests in October and November. Ultimately, COP25 took place in Spain, in violation of protocol that suggested it be held in a Latin American nation.

Some sectors of the Latin American economy are more vulnerable to having their assets "stranded" - that is, rendered value-less or unusable - by climate change, and by climate change mitigation policies, than others. For example, extensive fossil fuel resources in Latin America will need to go untapped if the region is to meet its Paris Agreement commitments - in effect, requiring nearly $50 \%$ of Latin America's oil and gas reserves, and $75 \%$ of its coal reserves, to stay in the ground. In particular, Argentina's vast Vaca Muerta shale reserves, which are the second largest source of untapped gas shale reserves in the world, would need to remain unexploited. Current Argentine president Alberto Fernandez, a left-leaning populist in the Kirchner mold, has expressed eagerness to develop the reserves, a process that requires hydraulic fracturing, or fracking. Leaving assets like this untapped would require a great deal of political compromise and a broad agreement about the dangers of global climate change, at a level that does not currently exist.

The search for alternative and renewable fuels will also have important strategic consequences for Latin American countries, particularly as they seek to fund those pro- 
jects with foreign capital. Chile's relationship with lithium is an illustrative example. No mineral in the world is expected to be more important during the coming century, given its importance in the production of batteries, especially those found in electric cars. Chile has the largest reserves of lithium in the world, according to the U.S. Geological Survey. As it stands, however, only two companies, both of them partly state-owned, exploit Chile's lithium. In 2017 Australia outpaced Chile to become the largest exporter of the mineral. Indeed, Chilean output of lithium has largely stagnated over the past five years, and its share of the global market has fallen from 36 percent to 20 percent. The sluggishness is largely driven by regulatory challenges, including a complex and vague application process for obtaining lithium mining permits, as well as still-undetermined taxation rates on lithium mining profits. Currently, Chile treats lithium as a "strategic" mineral under a law that dates back to the military dictatorship of general Augusto Pinochet and was designed with nuclear fission in mind. The Piñera government could easily change this law and eliminate the byzantine regulatory structure to encourage more private companies to enter the lithium market. Doing so would almost certainly lead to an immediate increase in private investment in lithium mining, though actual increases in production would lag many years behind.

However, opening up the Chilean lithium market raises strategic questions about who will profit from the high-value stages of lithium production. Chile will need to design an incentive structure that ensures that value is added to the lithium product prior to export. There is discussion of fostering battery production within Chile, and Chinese investors have pledged nearly a billion dollars toward factories in the country, in exchange for access to the raw lithium that Chile is producing. After all, refining rare earths is what gives China its geopolitical leverage over the international market. All of this is taking place while rare earths mining in neighboring Argentina and Bolivia is increasing dramatically and both of these countries will face similar decisions. All of these demonstrate the complex interwoven questions of strategy and climate that are involved in the transition to renewable fuels.

Agriculture poses perhaps the most vexing challenge to Latin American climate adaptation plans. Agriculture accounts for about $5 \%$ of regional GDP, but nearly $25 \%$ of exports from Latin America are agricultural products. Some have speculated that Latin American producers will actually benefit from climate change, acquiring a competitive advantage due to worsening conditions in other major crop producing regions of the world. The reality is unlikely to be that simple, however. First, water resources throughout Latin America, but especially in the mountainous regions of Central America and the Andes, are likely to be severely stressed in the coming decades, due to vast reductions in glacier melt-off as ice retreats and disappears. Adaptation to new water regimes can be accomplished via new irrigation techniques, but only to a limited extent. In Brazil, the effects of climate change on water availability will be more varied: a 2013 report by the Brazilian Panel on Climate Change found that northern Brazil would see rainfall decrease by $40 \%$ but that southern Brazil would see increases of $30 \%$. In general, the same trend will hold true for agriculture in Uruguay and Argentina. As a result, while yields for major staples like wheat and soybeans will likely drop when considered across the continent, there will be some limited yield increases due to improved fertility and rainfall in austral zones and zones now marginal to commodity production.

Some current staple crops simply cannot grow in warmer climates; coffee production, for example, is likely to be nearly impossible in elevations below 1000 meters above sea level by the year 2050, according to an International Panel on Climate Change re- 
port. Here, too, some limited adaptation measures are available, such as strategic use of shade-providing trees to keep plantations cooler. Similarly, in Argentina and Chile, wine production will likely prove challenging as vines suffer in high heat; vineyards at higher elevations will have an advantage as the warming continues, and in fact over the past decade wine production has gradually shifted to higher altitudes in both Chile and Argentina. When considering the agricultural future of a region as vast and diverse as Latin America, a complicated matrix of concerns related to water, temperature, carbon dioxide levels, and weather variability, make it impossible to make precise predictions. But it is certain that adaptation will come at a cost and it is equally certain that such geographic variability will create political problems that will tax the skills of policy makers.

But if there are risks to Latin America from climate change, there are also opportunities. No region in the world produces more of its energy from renewables than Latin America, but over $75 \%$ of that energy is produced by hydroelectric mega-dams, which are themselves vulnerable to the uncertainties of climate change and are increasingly viewed with disdain by environmentalists. Severe droughts have already caused massive electricity shortages in water basins that have staked their energy futures to hydropower - most famously in Brazil, where low reservoirs have led to power rationing and even outages in areas that rely on hydroelectric power. A growing awareness of the social and ecological costs of hydroelectric projects, not to mention the central role that megadams played in the sprawling Odebrecht corruption scandal, will only add to the political unpalatability of continued hydroelectric construction. Geopolitics also plays a role, especially in Ecuador, where the mega-dam projects have proved to be environmentally unsustainable and have pushed Ecuador into an unwanted dependence on Chinese creditors. A similar situation is emerging in Peru where the megaprojects are financed almost exclusively by Chinese capital. While the political turmoil in Peru has pushed geopolitical concerns into the background, in both countries there is considerable sensitivity to the influence over their affairs being exercised by China and Chinese investors.

By far the most important regional trends are toward solar and wind energy, which have seen price reductions of $87 \%$ and $37 \%$ respectively over the past decade. In terms of both natural resources and political will, Chile is perhaps the best positioned of any Latin American country to benefit from a future based on renewable energy. During his presidential campaign, current president Sebastian Piñera declared that by 2040, "Chile should have a $100 \%$ clean and renewable electricity grid and a $100 \%$ electric public transit system" - a bold goal, and notable coming from a conservative politician. Chile is endowed, though, with exactly the sorts of resources that will make it a renewable energy powerhouse: The Atacama Desert, in Chile's remote north, is quite literally the sunniest place on earth- nowhere else has higher long term solar irradiance. If the solar energy that reaches the Atacama were fully harnessed, it alone would be enough to provide electricity to all of Latin America at current levels.

Moreover, in late 2017, Chile completed the construction of long-awaited high-voltage transmission lines between the Atacama and Santiago. In doing so, the country solved a problem that had hindered the profitability of solar production in the north, since the energy couldn't be sold to Chile's urban population centers further south. The next goal for Chile, and its neighbors, should be to connect the solar plants in the Atacama into a regional power grid that includes Peru, Bolivia, Ecuador, and even Brazil. Perhaps the largest obstacle to this vision is the political aversion to large, multinational infrastructure projects in the wake of the Odebrecht scandal. 
The Atacama and the area surrounding it -a region that spans Chile, Bolivia, and Argentina- also boasts over half the global supply of lithium, the crucial ingredient in batteries that power electric vehicles and that store energy produced from solar and wind sources. Over the past five years, the global price of lithium has doubled (it now costs \$ 14.000 USD per metric ton). Developing lithium resources, and building capacity to create value-added products, is a vast potential source of income for Andean nations looking to profit off a global movement away from fossil fuels.

But all of these resources - water, lithium, solar, hydro, agriculture - must be considered on a regional level in order to have any effect at all. That raises the oldest national security question in Latin America: the tension between national interest and national security on the one hand and the management of resources or activities that by their very nature cross national boundaries. The struggle for control of water has been a subject of geopolitical concern for centuries. Today, with the question of climate change added to the mix, the challenge to geopolitical policymaking is more critical than ever.

If the Atacama is the future epicenter of solar and lithium production, Brazil's Atlantic coast may rival it for wind power. Benefitting from constant and unidirectional wind, the region attracted extensive outside investment between 2009 and 2015. Brazil's recent spate of economic and political crises has put a damper on further production, but government energy auctions scheduled for 2019 and 2020 are predicted to bring another 15 Gigawatts of wind power onto the grid. Mexico, Uruguay, and Argentina are also expanding their wind energy sectors.

South American economies, then, are extremely well-positioned to profit from global economic shifts toward green economies. This will, of course, require that governments and private actors recognize the urgency of making such investments now, while there is still a chance (if a dwindling one) of limiting warming to 1.5 degrees celsius. The differences between 1.5 and 2 degrees of warming are dramatic. Consider two different scenarios for Latin America's future, one in which global temperature rise is held to 1.5 degrees, and one in which it reaches 2 degrees:

In a 1.5 degree scenario, an average drought would last 5 months and 1 month in Central and South America, respectively. But in a 2 degree scenario, the average drought would be 8 months and 3 months, respectively. That would mean that, while about 18 million people would be exposed to water scarcity with 1.5 degrees of warming, nearly 25 million people would suffer from limited water resources under a 2 degrees scenario. Tropical diseases will become substantially more prevalent in Latin America under either scenario, with about 6 or 7 million people suffering dengue fever by 2050, under the 1.5 and 2 degree scenarios respectively.

Extreme weather, which jeopardizes growing conditions wherever it strikes, increases exponentially as global temperatures increase, with striking differences between the 1.5 and 2 degree scenarios. The Amazon region, for example, would experience a $258 \%$ increase in warm weather extremes under 1.5 degrees of warming, but a $737 \%$ increase in a 2 degree scenario. The Southern Cone would experience a 188\% increase in extreme warm weather under the 1.5 degree scenario, but a 553\% increase if warming exceeds 2 degrees.

Each scenario is a jarring new reality, and the impact of such warming would go beyond just rising temperatures. It will extend to the Latin American economy, as indus- 
tries seek to adapt to a changed environment. And it will extend to the political system, as policymakers seek to counteract new crises. Perhaps most troublingly, those who are likely to be most impacted by climate change are those who can least afford to adapt to the myriad changes it will bring.

Latin Americans who flee their homelands -- so-called climate refugees -- will become more and more common in the coming decades. Already, factors directly and indirectly related to climate are pushing more and more migrants out of Central America, particularly as coffee harvests become less reliable. A five-year drought in Central America's "dry corridor," on the Pacific Ocean, has led to a documented increase in emigration from the area. Increasingly, the northward flow of migrants from Central America is being understood as a climate phenomenon as well as a problem of social violence and citizen security. Any strategic solution to that problem will need to take climate into account.

Looking further ahead it is possible to imagine new areas of climate migration. Several major Latin American cities are extremely vulnerable to extreme weather events. One catastrophic event -a hurricane, an earthquake, or a drought-could potentially send a wave of migrants seeking a new home, perhaps on a scale that rivals the current exodus from Venezuela. A migration event on that scale would have enormous political and security consequences for the region.

The economic and political stability of Latin America will depend on the region's ability to cushion its marginalized poor from a brave new world of droughts and weather extremes, even as it seeks to capitalize on the business opportunities that it is so well positioned to benefit from. Climate change, like globalization, will have its winners and its losers. Latin America already is the most unequal region of the world. As the effects of climate change affect the most vulnerable the hardest, it will threaten governments with challenges they will struggle to meet.

And yet, urgent as questions related to climate are, they are likely in the short term to take a backseat to more pressing concerns around COVID-19 and, in many Latin American nations, and Chile in particular, broad protests around social inequality. This is a shame. Strategic planning for climate should go hand-in-hand with strategic planning around health security and national security. All three are inextricably interlinked. 